\title{
Interactive comment on "Data for wetlandscapes and their changes around the world" by Navid Ghajarnia et al.
}

\author{
Navid Ghajarnia et al. \\ navid.ghajarnia@natgeo.su.se \\ Received and published: 17 March 2020
}

Suggestions by Anonymous Referee \#2: I recommend the Authors to add to the manuscript the table with basic information of wetlandscapes showed in Figure 1. Uniform black dots used for showing the presented individual objects on the map suggest that these objects are of similar size. However, based on the data presented in "Survey summary doc A_General site information" show that presented wetlandscapes are in differ total area and percentage of wetlands. This information added in table into manuscript could provide this basic information for readers. In my opinion, key information is also altitude (mean in case of small objects and mean, maximum and minimum in case of large ones) and salinity. Moreover, small technical correction in "Survey summary doc A_General site information - site info" are recommended: unify of font 
and some detail information, eg. in some cases there is information "326102 number of people for watershed", however in the others "940 hab. (2002)", "Total population of 2.9 million people implies an average population density of _ 78 people per km2". It would be better to unify the way of presentation the population data, lakes data etc.

Response: Thanks for your feedback and suggestions. Based on your suggestion, we have now added Table 1 in section 3.1 of the revised manuscript. This table presents some selected fields of the "summary table sheet" in the "Survey summary doc A", including site names, country, classification (wetlandscape or individual wetlands), climate zone, wetland type, and area of wetlands relative to total wetlandscape (catchment) area. The total wetlandscape (catchment) area is not added in Table 1 as this information is embedded as a graph in Figure 2. Specific salinity levels are not included either, as such data have not been provided for the different sites, and the focus of the current version of the Wetlandscape Change Information Database (WetCID) is on land use and hydroclimatic changes, rather than on water quality. However, the wetland type for each site, which is given in Table 1, clarifies if there are mainly freshwater, brackish water, or saline water wetlands at each site. Various water quality data are definitely interesting to consider and include in further developments of the database. Moreover, altitude is also useful information to add in future developed versions of WetCID database, even though it has not been collected and prepared at this stage. The fonts, size and general format cells of Survey summary doc A are revised based on your recommendations (see the attached file). Different information items regarding latitude, longitude, climate zones, temperature, evapotranspiration, runoff, precipitation, groundwater table, and population, are also harmonized as much as possible. However, please note that, although we have defined a general structure for different existing fields in the survey forms (to harmonize reported data), we tend to keep additional information provided by each site's researchers, as this provides valuable local insights. Therefore, this may cause some minor inconsistencies in level of available data among different sites. The added Table 1 and its associated explanation in the revised manuscript are as follows: In the beginning of section 3.1, 
between lines 188-191: "Table 1 summarizes some general geographical, climate, and wetland type information provided by GWEN researchers in the survey information ESSDD forms. Each site represents either an individual wetland or a wetlandscape (e.g., a catchment) including multiple wetlands. The country, main climate zone and wetland area relative to total wetlandscape (catchment) area are also given for each site in Table 1."

Interactive

comment

Please also note the supplement to this comment:

https://www.earth-syst-sci-data-discuss.net/essd-2019-207/essd-2019-207-AC2-

supplement.zip

Interactive comment on Earth Syst. Sci. Data Discuss., https://doi.org/10.5194/essd-2019-207, 2019. 


\title{
ESSDD
}

1 Table 1. General geographic, climate, and wetland type information for the 27 investigated wetlandscapes in WetCID. The data and information are based on 2 survey responses by researchers with active research (on various topics) at each wetlandscape site.

\author{
Interactive \\ comment
}

\begin{tabular}{|c|c|c|c|c|c|c|}
\hline $\begin{array}{l}\text { Site } \\
\text { No. }\end{array}$ & Site name & Country & Classification & Climate zone & Wetland type & \begin{tabular}{|l|} 
Area of \\
wetlands \\
relative to total \\
catchment/wet- \\
landscape area \\
$(\%)$ \\
\end{tabular} \\
\hline 1 & Tavvavouma & Sweden & Wetlandscape & Subarctic & Peat plateau/thermokarst lake complex & 2.8 \\
\hline 2 & Forsmark & Sweden & Wetlandscape & Humid continental (cold summer) & Bogs, fens, marshes, (shallow lakes) & 0.01 \\
\hline 3 & Vattholma & Sweden & Wetlandscape & Humid continental (cold summer) & Bog, Fen, Riparian & \\
\hline 4 & North Baltic WMD & Sweden & Wetlandscape & Humid continental (cold summer) & \begin{tabular}{|l|} 
Multiple \\
\end{tabular} & 100 \\
\hline 5 & Simpevarp & Sweden & Wetlandscape & Humid continental (cold summer) & Bogs, fens & 0.01 \\
\hline 6 & South Baltic WMD & Sweden & Wetlandscape & Humid continental (cold summer) & Multiple & 100 \\
\hline 7 & Upper Lough Erne & Ireland & Individual wetland & Cold (dry winter, cold summer) & Flood plain/shallow lakes & 22 \\
\hline 8 & Selenga & Russia & Wetlandscape & Cold (dry winter, cold summer) & Marshes (Riverine, Palustrine) & 0.13 \\
\hline 9 & Volga & Russia & Wetlandscape & Cold (dry winter, cold summer) & Marshes (Riverine, Palustrine) & 1.0 \\
\hline 10 & Le Sueur & USA & Wetlandscape & Temperate & $\begin{array}{l}\text { isolated, fluvial/riparian, lakes/ponds, } \\
\text { marshes, forest/shrubs, constructed }\end{array}$ & 100 \\
\hline 11 & Sacca Di Goro & Italy & Individual wetland & Cold-summer Mediterranean & Shallow saltwater coastal lagoon & 4.2 \\
\hline 12 & Lake Urmia & Iran & Individual wetland & $\begin{array}{l}\text { Continental } \\
\end{array}$ & Lake & 8.8 \\
\hline 13 & Anzali Mordab & Iran & Individual wetland & Caspian or Hyrcanian climate & Inland and Marine/Coastal wetland & 4.0 \\
\hline 14 & Gialova Lagoon & Greece & $\begin{array}{l}\text { Individual wetland } \\
\end{array}$ & Hot-summer Mediterranean & Coastal wetland & 13 \\
\hline 15 & $\begin{array}{l}\text { Lower Mississippi River Delta } \\
\text { Plain }\end{array}$ & USA & Wetlandscape & Humid Subtropical & Riverine, Marine, Estuarine, Lacustrine & 3.5 \\
\hline 16 & Shadegan & Iran & Individual wetland & Warm desert & Palustrine, Estuarine, Marin & 31 \\
\hline 17 & Zone Humide de Souss & Morocco & Individual wetland & Mediterranean semi-arid & marine and coastal & 0.01 \\
\hline 18 & Geographically isolated wetlands & USA & Wetlandscape & Humid subtropical & Freshwater marshes and swamps & 100 \\
\hline 19 & Everglades & USA & Individual wetland & Tropical to Subtropical & Freshwater wetland, coastal wetland & 32 \\
\hline 20 & CGSM & Colombia & Individual wetland & Tropical & Estuarine & \\
\hline 21 & Mekong Delta & Vietnam & Wetlandscape & Tropical Monsoon & Marine & 5.0 \\
\hline 22 & Panama Canal & Panama & Wetlandscape & Tropical/Central America & River Chagres, Lake & 100 \\
\hline 23 & León-Atrato & Colombia & Wetlandscape & Tropical rainforest & Marshes and Swamps & 17 \\
\hline 24 & Lagunas Plaza and Grande & Colombia & Wetlandscape & Extremely cold and very dry & Glacial Lake & 4.4 \\
\hline 25 & Fúquene, Cucunubá y Palacio & Colombia & Individual wetland & Cold and very dry & Natural shallow lake & 1.7 \\
\hline 26 & Paramo Sumapaz & Colombia & Wetlandscape & Tropical & High altitude wetland & 46 \\
\hline 27 & Pantanal & Brazil & Wetlandscape & Tropical savanna with dry-winter & Periodically inundated savanna & 27 \\
\hline
\end{tabular}

Fig. 1. Table 1. General geographic, climate, and wetland type information for the 27 investigated wetlandscapes in WetCID 